\section{The Predictive Power of Elementary School Students' Trait Anxiety Level in Physical Education Lesson on Their Attitudes towards Lesson}

\author{
Yaprak Kalemoğlu Varola
}

\author{
Received: 12 July 2018 \\ Revised: 01 October 2018 \\ Accepted: 10 October 2018 \\ ISSN: 1307-9298 \\ Copyright (C) IEJEE \\ www.iejee.com
}

Abstract

The aim of this study is to determine the predictive power of elementary school students' trait anxiety level in physical education (PE) lesson on their attitudes towards lesson. The study group consisted of 590 elementary school students $(M=11.46$ years, $S D=0.63)$. In addition to the descriptive statistics, inferential statistics were used in this research like correlation and regression analysis. At the end of the study, it was observed that course on the attitudes of trait anxiety effect size to have a low level of trait anxiety subscale attitude towards the course of the variables that make up $3 \%$ of the total variance explained in the levels. Besides, it was identified that students' attitudes towards physical education classes are high, the physical education lesson is a medium level of trait anxiety. Gender-related differences were not significant in the students' trait anxiety and attitudes towards the lesson.

Keywords: Attitudes, Anxiety, Trait Anxiety, Elementary Education, Physical Education Lesson

\section{Introduction}

Physical education lesson, to achieve the goals of education is just one of the tools used to but perhaps the most fun and is most effective when used correctly (Öztürk, 1998). Physical education in school curricula is defined as a form of development for students with physical activities, knowledge, attitudes, motor and behavioural skills for the purpose of participating fun and active life that includes physical continuity (Pate, Corbin, \& Pangrazi, 1998). Physical education lesson in general, although fun course among students by many students to learn and practice may be perceived as a difficult subject. Studies such as getting pleasure from physical education classes generally positive affective experiences are also observed (Barr-Anderson, Neumark-Sztainer, Schmitz, Ward, Conway, Pratt, Baggett, Lytle, \& Pate, 2008), physical education lesson is an important determinant of being experienced in the state of anxiety, achievement goals, effort, and learning strategies as well as performance and performance-related information (Cury, Da Fonséca, Rufo, Peres, \& Sarrazin, 2003).

Phillips (1984) also stated that one of the important factors that affect the learning process is anxiety. Very low and high anxiety levels that make it more difficult to learn, a medium anxiety simplifies learning and encourages (Seven \& Engin, 2008). Genetic and biological factors, learnings, experience and the living environment of the concern caused by the stimulus (Kutlu, 2001), were classified in two ways by Spielberger, as trait anxiety and state anxiety (Cheng \& Cheung, 2005). State anxiety is the emotional response of people with special situations as threatening as a result of interpretation (Kutlu, 2001). The trait anxiety was expressed as a threat to their specific situations and against this tendency to increase the level of state anxiety (Spielberger, 1966, qtd. in Martens, Vealey, \& Burton, 1990).

The field of physical education and sports in the some studies related concerns were investigated concerns for mostly students or athletes in a class of non-specific anxiety levels
(Ariza-Vargas, Domínguez-Escribano, López-Bedoya, \& Vernetta-Santana, 2011; Chamanabadi, Pooladiborj, Esmaeili, \& Zamani, 2012; K.meswania, 2012; Selmi, Selmi, \& Hermassi, 2013). In some studies, a variety of concerns related to physical education and sports activities for children and young people in reducing anxiety levels were also investigated (Dalkıran \& Tuncel, 2007). However, in terms of content and teaching methods are different in other areas of education physical education lesson is especially important to live in the state of anxiety. Considering the fact that physical education lesson is predominant in physical skills and that evaluations are made in front of students' peers, situations such as students' inadequacy of their peers, failure, injury and body image concerns (Shepard \& Trudeau, 2000; Tremayne, 1995) can be seen intensively. It was thought that this kind of concerns could be reflected in the students' reluctance towards physical education lesson, shyness and negative attitude.

Attitudes shape human behaviour in different ways determines participation in everyday activities and shapes behaviour of people as a condition to accept or leave. (Rikard \& Banville, 2006). According to Morris, the attitude is composed of three components are known as thoughts, feelings, and behaviours. Our thoughts basic information about an object has been explained as (i.e., physical education and sports classes in terms of understanding the importance of the human health), as we like and what we feel like sense objects (i.e., physical education and sports lesson love and dislike), the behaviour that we exhibit our actions against objects (i.e., continuous participation in physical education and sports classes) (Demirhan \& Altay, 2001; Morris, 2002).

School lessons in the context of attitude; represent the sum of feeling, beliefs and values of that lesson (Osborne, Simon, \& Collins, 2003). In other words, to have a positive or negative thought about lesson, of a course, like and dislike and consequently is studying cognitive, including affective and behavioural characteristics (Bloom, 1995). Located in courses related to physical education lesson at each course that the student can develop a positive or negative attitude (Demir- 
han \& Altay, 2001). The fact that students have positive attitudes toward PE lesson can make the lessons more effective and also it can facilitate students' achieving their specific or general aims (Silverman \& Scrabis, 2004). The first objective of physical education lesson in the students develop positive attitudes and life-long physical activity contribute to raising given that is also an important factor in achieving positive attitudes about the course developed for efficient processing (Demirhan \& Altay, 2001; NASPE, 1995) together with the objectives of education.

This age group of children in physical education lesson and fun activities generally look upon the game as less capable physically they are thought to be concerned for the children's classes is a condition observed. However, increasing rise in obesity among children in this age group, in children can be seen this with restricted mobility concerns over the course of development. This anxiety in students is thought to be in the case of on attitudes towards physical education lesson also cause adverse effects. Indeed, many studies examining the relationship between attitude and anxiety in students' attitudes towards students with a course for that course has been a close relationship between anxiety (Baloğlu, Koçak, \& Zelhart, 2007; DeVaney, 2010; Doğan \& Çoban, 2009; Finney \& Schraw, 2003; Hussain, 2011; Kurbanoğlu \& Takunyacı, 2012; Onwuegbuzie, 2000; Yenilmez \& Özabacl, 2003). Onwuegbuz (2000) in his study in the field of statistics has indicated that anxiety level is the determinant of a student's attitude. Finney and Schraw (2003) have found a negative relationship statistically significant correlation between anxiety and attitudes. Yenilmez and Özabaci (2003) stated that mathematics attitude is a high correlation between math anxieties, with regard to mathematics students have a positive attitude towards the course that allows being successful, and that it lowers the anxiety level. Baloglu, Kocak and Zelhart (2007) have examined the relationship between statistics anxiety with college students' attitudes towards statistics and have found that student's anxiety is high according to negative attitude towards this course Doğan and Çoban (2009) in their study with faculty of education students, have found a negative and significant relationship in students' attitudes towards the profession and with low levels of anxiety. De Vaney (2010) in his work in the field of statistics concluded that the low anxiety level was associated with more positive attitudes. Kurbanoğlu and Takunyaci (2012) stated that self-efficacy beliefs of the students and the development of positive attitudes would reduce the level of anxiety towards mathematics. Hussain (2011) in his study found significantly negative relationship between English learning and English anxiety. Nevertheless, Bekdemir (2007) as stated that anxiety is one of the factors in the formation of negative attitudes. When individuals develop negative attitudes about any subject, they do not love it, interest is reduced and that increases failure. Attitudes affect success, success affects attitude. Negative attitudes developed due to the problems caused by the education of individuals or the environment, over time, reflected in behaviour, after a period of time form a failure cycle. In this case, with failure prejudice of individuals increases the likelihood of experiencing anxiety.

Physical education lesson for a serious problem in adolescence age with physical education lesson for the attitude (Akandere et al., 2010; Butcher \& Hall, 1983; Portman, 1995; Subramaniam \& Silverman, 2007) and physical activity and physical education lesson to participate in the reduction (Ntoumanis, Barkoukis, \& Thogersen-Ntoumani, 2009; Sallis, Prochaska, \& Taylor, 2000) of probable cause as one of the physical education lesson developed for the continuous state of anxiety and with it physical education or physical activity developed against, negative attitudes are thought to be. Thus, if students can develop positive attitudes towards in elementary school physical education and physical activity, the experienced problems considered to be avoided in adolescence. To develop positive attitudes towards physical education classes and classes that reduced levels of trait anxiety in realizing the goals of education has an important place in physical education classes and is important in order to ensure the highest level of benefits. In addition, attitudes towards physical activity at a young age that earned considering the positive attitude toward the course, especially if ensured in this period, in children of lifetime sports consciousness can contribute to the settlement.

Studies in the field of anxiety and attitudes related to physical education examined that there is no study between the relationship of anxiety and attitudes towards physical education lesson. Therefore, to determine the elementary school students' physical education lesson for the trait anxiety levels and attitudes, however, may be useful for the physical education lesson levels of trait anxiety, attitudes towards the course on the extent to be effective detection.

\section{Method}

\section{Research Group}

The research group, consisted of 590 various primary and secondary schools students selected through random sampling studying in Ankara $\left(M_{\text {age }}=11.46, S D=0.63\right)$.

\section{Data Collection Tools}

"Physical Education Trait Anxiety Scale (PETAS)" and "Elementary Physical Education Attitude Scale (EPEAS)" were used as data collection tool.

Physical Education Trait Anxiety Scale. "Physical Education Trait Anxiety Scale" (The Physical Education Trait Anxiety Scale) was developed by Barkoukis, Rodafinos, Koido and Tsorbatzoudis (2012), and adapted to Turkish by Kalemoğlu Varol (2014). Scale as the original form was formed by 3 factors as "cognitive processes", "somatic anxiety" and "worry", and the total of 18 items. There are 6 items in each dimension. It was graded as Scale (1) strongly disagree, (5) strongly agree as 5 point Likert-type scale. All items are positive statements in the scale and higher scores represent higher levels of anxiety. Scale showed high internal consistency and test-retest reliability. Cronbach's alpha coefficients of internal consistency; was found to be .93 for the subscales of cognitive processes, for somatic anxiety sub-factor 97 , for sub-factor for concern .98 and for the whole scale .94. The test-retest reliability coefficient is .96. Confirmatory factor analysis of the results obtained in the higher compliance values, showed 3 factors of verification of the structure of the scale (RMSEA $=0.064, \mathrm{NFI}=0.97$, $\mathrm{NNFI}=0.98, \mathrm{CFI}=0.99, \mathrm{SRMR}=0.033, \mathrm{GFI}=0.88$ ve $\mathrm{AGFI}=$ 0.84).

Elementary Physical Education Attitude Scale. Elementary Physical Education Attitude Scale was developed by Phillips and Silverman (2012) and adapted to Turkish by Kalemoğlu-Varol, Erbaş, Ünlü and Sünbül (2014). The scale is composed of a total of 15 items including 7 negative, 8 positives. Scale items are grouped under the so-called "cognitive" and "affective" factors. Likert-type scale response code will be given to each item ranged from 1.00 to 5.00. Rating agents consist of "1-strongly disagree, 2-Disagree, 3-Undecided, 4-Agree, 5-Strongly Agree" options. The lowest score that can be obtained from the scale 15 and the highest score was 75, and higher scores represent higher levels of attitude. Scale showed high internal consistency and test-retest reliability. Cronbach's alpha coefficients of internal consistency; was found to be .96 for the subscales of cognitive processes, for sub-factor for 
concern .95 and for the whole scale .83 . The test-retest reliability coefficient is .77 . All of the differences between item means of supergroups and subgroups with $27 \%$ were found meaningful. Confirmatory factor analysis values obtained showed that it is 2 factors in the alignment of the scale factor structure verification (RMSEA $=0.06, \mathrm{CFI}=0.99$, $\mathrm{SRMR}=0.03, \mathrm{GFI}=0.93$ and $\mathrm{AGFI}=0.89$ ).

\section{Data Analysis}

In the study, the distribution was examined prior to data analysis. It was found that the data was consistent with distribution by the Lilliefors and Kolmogorov-Smirnov test, Histogram graphics and normal distribution curve, and skewness and kurtosis. In the study, the arithmetic means of the items that were included in each subscale were calculated and after this calculation the score was determined for each relevant factor. The analysis was performed via these factor scores. In the analysis of data; Descriptive statistics and $t$-test for independent groups, in order to determine the relation. Also, Pearson Moments Multiplication Correlation Coefficient technique was used in order to identify the relationship. Furthermore, Multiple Linear Regression Analysis was employed with the purpose of determining the predictive power of the independent variables on the dependent variables. In these analyses, each of the PE trait anxiety scale's sub-factor scores were taken as independent variables, and the at titude towards Physical Education was accepted as the dependent variable. In the interpretation of the data, 0.01 and 0.05 significance levels were used. The data obtained in the research was analysed with SPSS 23 software.

\section{Results}

In the study group of the students' attitudes towards physical education lesson with average scores on trait anxiety levels and standard deviation values are given in Table 1.
Table 1. Elementary school students' physical education and attitude levels of trait anxiety

\begin{tabular}{lccc}
\hline Variables & $n$ & $M$ & $S D$ \\
\hline Trait Anxiety Total & 590 & 52.00 & 9.59 \\
\hline PE Lesson Attitude Total & 590 & 39.95 & 14.36 \\
\hline
\end{tabular}

Analyzing the Table 1; of elementary school students in physical education lesson middle of trait anxiety $\left(M_{\text {anxiety }}=39.95, S D=14.36\right)$, course attitude was found to be $\operatorname{high}\left(M_{\text {attitude }}=52.00, S D=9: 59\right)$.

\section{Trait Anxiety Level and Course Attitude According to Gender}

Table 2 presents the results of the analysis to determine whether the students' trait anxiety levels and the attitudes of the students differ according to gender variable.

Analyzing Table 2, physical education lesson in attitude and trait anxiety levels were not observed significant differences by gender $(p>.05)$.

The relationship between trait anxiety level and the attitude towards the lesson

The relationship between trait anxiety level and attitudes toward the PE lesson was tried to be determined and analysis results were given in Table 3.

Analyzing Table 3, the cognitive subscale of the scale of physical education, trait anxiety subscale of the scale and the low level of concern a relationship was found to be negatively $(r=-.134 ; p<.01)$.

It was tried to determine predictive power of trait anxiety levels on attitudes towards the lesson and results of analysis were given in Table 4.

Table 2. Trait anxiety levels and course attitude according to gender

\begin{tabular}{|c|c|c|c|c|c|c|c|}
\hline Variables & Gender & $n$ & $M$ & $s d$ & $d f$ & $t$ & $p$ \\
\hline \multirow[t]{2}{*}{ Trait Anxiety Total } & Female & 330 & 40.47 & 14.85 & \multirow{4}{*}{588} & \multirow{2}{*}{996} & \multirow{2}{*}{320} \\
\hline & Male & 260 & 39.29 & 13.71 & & & \\
\hline \multirow{2}{*}{ PE Lesson Attitude Total } & Female & 330 & 54.71 & 9.24 & & \multirow{2}{*}{.976} & \multirow{2}{*}{.631} \\
\hline & Male & 260 & 54.68 & 10.12 & & & \\
\hline
\end{tabular}

Table 3. The relationship between trait anxiety level and course attitude

\begin{tabular}{|c|c|c|c|c|c|}
\hline VARIABLES & $C$ & $A$ & $\mathrm{CP}$ & SA & W \\
\hline Cognitive $(C)$ & 1 & & & & \\
\hline Affective (A) & .026 & 1 & & & \\
\hline Cognitive processes (CP) & -.003 & -0.44 & 1 & & \\
\hline Somatic Anxiety (SA) & .068 & -0.44 & $.718^{* \star}$ & 1 & \\
\hline Worry (W) & $-.134 * *$ & -0.15 & $.633^{* *}$ & $.631 * \star$ & 1 \\
\hline Mean & 26.40 & 25.60 & 12.98 & 12.66 & 14.30 \\
\hline Standart Deviations & 6.80 & 6.59 & 5.16 & 5.35 & 5.81 \\
\hline
\end{tabular}

Table 4. The prediction of the trait anxiety level on the attitude (cognitive) towards the PE lesson

\begin{tabular}{lrrrrrrr}
\hline Variables & $B$ & Standard Error & $\beta$ & $t$ & $p$ & Dual $r$ & Partial $r$ \\
\hline Constant & 24.974 & .819 & & 30.491 & .000 & & \\
\hline Cognitive Anxiety & -.243 & .081 & -.185 & -2.989 & $.003^{*}$ & -.003 & -.123 \\
\hline Somatic Anxiety & .090 & .078 & .071 & 1.149 & .251 & .068 & .047 \\
\hline Worry & .241 & .065 & .206 & 3.713 & $.000^{* *}$ & -.134 & .152 \\
\hline$R=0.182$ & \multicolumn{7}{c}{$=0.033$} \\
\hline$F=6.690$ & $p=.000$ \\
${ }^{*} p<.05^{* *} p<.01$ & & & & \\
\hline
\end{tabular}


Analyzing the findings in Table 4, the course of trait anxiety attitude (cognitive dimension) procedure equation $(R=$ $.182, p<.01$ ) is important. Trait anxiety level courses illustrate the attitude of $3 \%$ of the total variance. The standardized regression coefficient (ß) of the predictor variables based on the relative order of importance concerns the attitude of course, is form of cognitive processes and somatic anxiety. Conclusions regarding the significance of regression coefficients examined the lessons of the sub-dimensions of anxiety and cognitive processes to be significant predictors of attitudes, whereas somatic anxiety variable was found to be a significant variable. In line with these results, levels of trait anxiety attitude on course to have a low level of effect size were determined.

\section{Discussion and Conclusion}

In the study of elementary school students in physical education lesson at the middle level is the level of trait anxiety were identified. There is no study to support these findings directly. However, as the age group classes and many students often fun (Barr-Anderson et al., 2008) considering that look already high anxiety level is not expected. However, in the mid-level anxiety about whether a course totally fun and enjoy indicator has been received. Thus in future studies that the examination of the factors behind the anxiety score is deemed beneficial.

Another result obtained from the study of students' attitudes towards physical education classes is that positive. Similarly Trudeau and Shephard (2005) in a study conducted by high school students attitudes towards the course grade level but now they have a level that is indicated by a decrease in attitude. Subramaniam and Silverman (2007) in studies conducted with middle school students by The students' attitudes towards physical education classes were found to be medium level.

Students in physical education classes trait anxiety levels when analyzed by gender (Table 2), the physical education of trait anxiety scale total score was found to be higher than male students. There is no study to support these findings directly. However, physical activity, anxiety, and other areas of concern identified studies related to the level of research findings are examined in parallel with studies (Ginsburg \& Silverman, 2000) have been found. The idea that women are more anxious than men is not a new idea. Kierkegaard (2009) also stated that women than men are concerned that, this situation women's physical weakness, not from the essentially spiritual in nature due to the fact that spirituality increases anxiety increases. Related to physical education and sports activities, girls are physically more delicate than men and have more reservations because of the structure, physical education classes to be related to high levels of trait anxiety is a condition generally expected. However, research findings large number of non-overlapping of work, considering the constant concern of physical education classes differed by gender in order to determine whether, numerous studies are needed.

Students' attitudes towards physical education lesson when analyzed by gender (Table 2), a significant difference between boys and girls was observed. This finding limited number of trial paralleled the (Chatterjee, 2013; Subramaniam \& Silverman, 2007), many research results that does not coincide (Akandere et al., 2010; Chung \& Phillips, 2002; Kjonniks, Fjørtoft \& Wold, 2009; Stelzer, Ernest, Fenster, \& Langford, 2004; Şişko \& Demirhan, 2002). The difference between the research findings may be due to the fact that the attitude scales used are not the same. As well as samples of the properties to be different, the girls grow where they, their parents attitude towards the course and level of education, the instructional methods of teaching such research to be covered latent variables also finding differences in cause is thought to be. Women to participate in the Olympic Games in Ancient Greece, and even where it is forbidden even to keep track, considering men than women may be assumed to have a positive attitude. Because of lifelong fitness habits from a young age gain, considering that the male body during puberty education and more active participation in sports activities, has brought a positive attitude. However, as of today be considered that this situation begins to change shape. As a result of the major factors to be formed in this way, together with social changes occurring nowadays women are more involved in sporting activities, and with it an increase in sporting success can be considered. In parallel to this increase in society, girls and adolescents as motivation in the face of this success, in that a positive attitude towards physical education and sports activities are thought to be influential in the development. However, for girls to lose weight and usually consists of just walking though they started to move their body in a way that is seen. Different genders secondary school students' physical education from the expectations upon a survey conducted, the physical education lesson developed with the physical appearance related to the objectives of secondary education for students is very important that have been identified (Yıldıran, Yetim, \& Şenel, 1996). Daughter of the mass media in positive attitudes towards physical activity is thought to be the effect. Visual and written media dietitians often lose weight and stay in shape for the sport's emphasis on the importance to do, television, newspapers and magazines as well as the means of communication to more people arrive and these media outlets sports content the diversity of programs to increase such reasons in this direction, which is effective as factors considered. All these factors in the formation of positive attitudes towards sports in reducing the impact of gender factor. Also included in the study group of girls to their parents' attitudes towards physical education and sports activities can be considered as the effect on this result. As Silverman and Scrabis (2004) state that parents' attitudes towards physical education course are positive, they can facilitate the efficient processing of lesson activities for the students and make it easier for the students to achieve their specific and general goals, or to provide students with voluntary participation in various physical activities in the future.

Physical education trait anxiety subscales with physical education lesson attitude relationship between the level examined (Table 3), anxiety subscales of physical education attitude cognitive dimension with the low-level negative relationship was found. Thus, with increasing concern in primary school students in physical education lesson can be said that the attitude adversely affected. Related literature research has found thatscanned trait anxiety of elementary school students in physical education and physical education courses directly examine the relationship between attitudes. Therefore, it has not been reviewed compared with the findings of other research findings. However, the findings in other areas, concerns and attitudes examined the relationship between work, attitudes and concerns of a negative relationship finding that is in line (Baloğlu, Koçak, \& Zelhart, 2007; DeVaney, 2010; Doğan \& Çoban, 2009; Finney \& Schraw, 2003; Hussain, 2011; Kurbanoğlu \& Takunyacı, 2012; Onwuegbuzie, 2000; Yenilmez \& Özabacl, 2003). The education of individuals or the environment they have developed due to the problems caused by negative attitudes, behavior, reflected over time, after a period constitutes a failure cycle. Individuals will not succeed in this case with prejudice is thought to increase the likelihood of experiencing anxiety.

Also somatic anxiety size cognitive processes with the size of a positive high level, anxiety size cognitive dimension positively with moderate and concerns size somatic anx- 
iety size is positively correlated with intermediate having a relationship that has been found. Both cognitive and somatic anxiety concerns the size of the size of a positive result is expected to be in a relationship. Physical education trait anxiety scale concerns subscale statements contained in students' overall course related movements during the error to be made or misfortune will face the anxiety and examination regarding his concerns about the level of trait anxiety for measuring the statements (eg, I am very worried about physical education exams, physical education lesson in the I feel uneasy, fearing I will make mistakes). This condition may occur in a state of anxiety, and cognitive anxiety (e.g., I have difficulty focusing on movements in physical education lesson) and somatic anxiety (e.g., in physical education lesson while the movements my body aches) levels may cause an increase.

In the study, it was determined that trait anxiety subscale on the attitudes of the physical education lesson has a low level of effect size (Table 4). In addition, levels of trait anxiety in physical education lesson, the impact on attitudes towards the course is described by a ratio $3 \%$. In the study, only physical education lesson continuously lowering of anxiety levels, attitudes towards the course has not proved sufficient to increase. Attitudes towards physical education lesson by researchers to investigate the factors affecting attitudes towards the course and to move to a higher level can be made more concrete proposals.

Studies examining the relationship between achievement and attitudes of students towards the course with the attitude of a student's success in those courses showed a close relationship between them (Büyüköztürk, 1999). Because of the close relationship between achievement and attitudes of all students by providing tasting success in physical education lesson, along with a sense of achievement in a positive attitude towards the course of the development can be achieved. Together in a positive attitude towards physical education lesson in trait anxiety will decrease. In the study of elementary school students have a positive attitude towards physical education lesson, despite this positive attitude despite the low level of anxiety was observed. In mathematics, a study conducted in the attitude towards the course along with students 'self-efficacy beliefs in a positive way to develop lesson concerns reduce the level (Kurbanoğlu \& Takunyaci, 2012) as a result of considering the obtained results of the research of the students' self-efficacy low levels could arise from the possibility that suggests. In addition, a study done, which is more physically fit students, physical education and physical activity that results in more positive attitudes toward reached (Sherrill, Holguin \& Caywood, 1989). This may help us to think that students are not able to prevent anxiety because they love the lesson and develop a positive attitude but are physically inadequate. These levels despite a positive attitude along with low levels of trait anxiety as the cause of the lack of parental attitudes and level of education, physical education teachers' approaches and attitudes in various factors such as the effect is thought to be.

However, it is thought that can bring to contribute to the field of study of a single province in the city center, in a selected group of students, it is preventing making and generalization of the results of the study group relatively small. The research of elementary school students in physical education lesson attitude towards the course of trait anxiety levels to determine the predictive power is the first study in the context of the future work to be done in this area and thought to shed light on this. Therefore, different samples are needed to work in the similar area. This type of study, students in physical education lesson trait anxiety and attitudes related physical education lesson is expected to be useful for a better understanding.

\section{References}

Akandere, M., Özyalvaç, N.T., \& Duman, S. (2010). Orta öğretim öğrencilerinin beden eğitimi dersine yönelik tutumları ile akademik başarı motivasyonlarının incelenmesi. S.Ü. Sosyal Bilimler Enstitüsü Dergisi, 24, 1-10.

Ariza-Vargas, L., Dominguez-Escribano, M., Lopez-Bedoya, J., \& Vernetta-Santana, M. (2011). The effect of anxiety on the ability to learn gymnastic skills: $A$ study based on the schema theory. The Sport Psychologist, 25, 127-143.

Baloğlu, M., Koçak, R., \& Zelhart, P.F. (2007). The relationships between statistics anxiety and attitudes toward statistics. Ankara University Faculty of Educational Sciences Journal, 40(2), 23-39.

Barkoukis, V., Rodafinos, A., Koidou, E., \& Tsorbatzoudis, H. (2012). Development of a scale measuring trait anxiety in physical education. Measurement in Physical Education and Exercise Science, 16(4), 237-253.

Barr-Anderson, D.J., Neumark-Sztainer, D., Schmitz, K.H., Ward, D.S., Conway, T.L., Pratt, C., Baggett, C.D., Lytle, L., \& Pate, R.R. (2008). But I like PE: Factors associated with enjoyment of physical education class in middle school girls. Research Quarterly for Exercise and Sport, 79, 18-27.

Bekdemir, M. (2007). The causes of mathematics anxiety in elemantary preservice teachers and proposals for decreasing mathematics anxiety. Journal of Erzincan Education Faculty, 9(2), 131-144.

Bloom, B. (1995). Human Characteristics and School Learning [insan nitelikleri ve okulda öğrenme]. (Translation: D.A. Özçelik). İstanbul: Milli Eğitim Yayınları. (Orijinal published 1983)

Butcher, J., \& Hall, M.A. (1983). Adolescents girls' participation in physical activity. (ERIC Document Reproduction Service No. ED 231777).

Chamanabadi, G.E., Pooladiborj, H., Esmaeili, B., \& Zamani, M.T. (2012). A study of the effect of an aerobic training program on the level of trait anxiety in high school students od khauf county. European Journal of Experimental Biology, 2(4), 1103-1105.

Chatterjee, S. (2013). Attitudes toward physical education of school going adolescents in west Bengal. International Journal of Innovative Research in Science, Engineering and Technology, 2(11), 6068-6073.

Cheng, C., \& Cheung, M.W.L. (2005). Psychological responses to outbreak of severe acute respiratory syndrome: A prospective, multiple time-point study. Journal of Personality, 73(1), 261-285.

Cury, F., Da Fonseca, D., Rufo, M., Peres, C., \& Sarrazin, P. (2003). The trichotomous model and Investment in learning to prepare for a sport test: A mediational analysis. British Journal of Educational Psyshology, 73, 529-543.

Dalkıran, O., \& Tuncel, F. (2007). Ortaöğretim kurumlarında beden eğitimi dersinin seçmeli ders olarak işlenmesinin öğrenciler gözüyle değerlendirilmesi. Spormetre, 5(1), 37-42.

Demirhan, G., \& Altay, F. (2001). Attitude scale of high school first graders towards physical education and sport II. Hacettpe Journal of Sport Sciences. 12(2), 9-20. 
DeVaney, T.A. (2010). Anxiety and attitude of graduate students in on-campus vs. online statistics courses. Journal of Statistics Education, 18(1), 1-15.

Doğan, T., \& Çoban, A.E. (2009). The ınvestigation of the relations between students' attitude toward teaching profession and anxiety level in faculty of education. Education and Science, 34(153), 157-168.

Finney, S., \& Schraw, G. (2003). Self-efficacy beliefs in college statistics courses. Contemporary Educational Psychology, 28, 161-186.

Ginsburg, G.S., \& Silverman, W.K. (2000). Gender role orientation and fearfulness in children with anxiety disorders. The Journal of Anxiety Disorders, 14, 57-67.

Hick, M.K., Wiggins, M.S., Crist, R.W., \& Moode, F.M. (2001). Sex differences in grade three students attitudes toward physical activity. Perceptual and Motor SkilIs, 93, 97-102.

Hussain, M.A. (2011). Relationship of classroom environment with anxiety and attitude of secondary school students towards the learning of english. PhD Thesis, International Islamic University, Islamabad.

K.meswania, N. (2012). A study of anxiety level in selected players of various schools sports and non-players. International Global Research Analysis, 1(4), 65-66.

Kalemoğlu Varol, Y. (2014). Turkish adaptation of the physical education trait anxiety scale: The validity and reliability study. International Journal of Human Sciences, 11(1), 221-235.

Kalemoğu Varol, Y., Erbaş, M.K., Ünlü, H., \& Sünbül, A.M. (2016). Turkish Adaptation of the Elementary Physical Education Attitude Scale. Hacettepe Journal of Sport Sciences, 27(1), 16-26.

Kierkegaard, S. (2009). Kaygı Kavramı (Translation: T. Armaner), İstanbul: Türkiye İş Bankası Kültür Yayınları.

Kjonniksen, L., Fjortoft, IN, \& Wold, B. (2009). Attitude to physical education and participation in organized youth sports during adolescence related to physical activity in young adulthood: A 10-year longitudinal study. European Physical Education Review, 15, 139-154.

Kurbanoğlu, N.í., \& Takunyacı, M. (2012). An ınvestigation of the attitudes, anxieties and self-efficacy beliefs towards mathematics lessons high school students' in terms of gender, types of school, and students' grades. International Journal of Human Sciences, 9(1), 110-130.

Kutlu, Ö. (2001). Ergenlerin üniversite sınavlarına ilişkin kaygıları. Eğitim ve Bilim, 26(121).

Martens, R., Vealey, R., \& Burton, D. (1990). Competitive Anxiety in Sport. Champaign, IL: Human Kinetics.

Morgan, C.T. (2000). Introduction to Psychology. [Psikolojiye giriş]. (Translation: Hüsnü Arıcı \& Orhan Aydın). Ankara: Meteksan. (Original published 1986)

Morris, C.G. (2002). Understanding Psychology. [Psikolojiyi anlamak: Psikolojiye giriş]. (Translation: H.B. Ayvaşık, M. Sayıl) Ankara: Türk Psikologlar Derneği Yayınları, No:23, 525-567. (Original published 1992)

National Association for Sport and Physical Education (NASPE), (1995). Moving into the Future: National Physical Education Standarts: A Guide to Content and
Assessment. Boston: CB/McGraw-Hill.

Ntoumanis, N., Barkoukis, V., \& Thogersen-Ntoumani, C. (2009). Developmental trajectories of motivation in physical education: Course, demographic differences and antecedents. Journal of Educational Psychology, 101, 717-728.

Onwuegbuzie, A.J. (2000). Attitudes toward statistics assessments. Assessment and Evaluation in Higher Education, 25, 321-339.

Osborne, S., Simon, S., \& Collins, S. (2003). Attitudes towards science: A review of the literature and its implications. International Journal of Science Education. 25(9), 1049-1079.

Öztürk, F. (1998). Toplumsal Boyutlarıyla Spor. Ankara: Bağırgan Yayımevi.

Pate, R., Corbin, C., \& Pangrazi, B. (1998). Physical activity for young people. The President's Council on Physical Fitness and Sports Research Diegest, 3(3), 1-6.

Phillips, D. (1984). The Illusion of Incompetence among academically component children. Child Development, 55(6), 2000-2016.

Portman, P.A. (1995). Who is having fun in physical education classes? Experiences of six grade students in elementary and middle school. Journal of Teaching in Physical Education, 14, 445-453.

Rikard, L., \& Banville, D. (2006). High school student attitudes about physical education. Sport, Education and Society, 11(4), 385-400.

Sallis, J.F., Prochaska, J.J., \& Taylor, W.C. (2000). A review of correlates of physical activity of children and adolescents. Medicine \& Science in Sports \& Exercise, 32(5), 963-975.

Selmi, H., Selmi, W., \& Hermassi, S. (2013). Sportivisation impact of physical education on state anxiety and mood states of secondary students. International Journal of Scientific and Research Publications, 3(8), 1-6.

Seven, M.A., \& Engin, A.O. (2008). Öğrenmeyi etkileyen faktörler. Atatürk Üniversitesi Sosyal Bilimler Enstitüsü Dergisi, 12(2), 189-212.

Shephard, R.J. \& Trudeau, F. (2000). The legacy of physical education: Influences on adult lifestyle. Pediatric Exercise Science, 12, 34-50.

Sherrili, C., Holguin, O., \& Caywood, A.J. (1989). Fitness, attitude toward physical education, and self-concept of elementary school children. Perceptual and Motor Skills, 69(2), 411-414.

Silverman, S., \& Scrabis, K.A. (2004). A review of research on instructional theory in physical education 20022003. International Journal of Physical Education, 41(1), 4-12.

Stelzer, J., Ernest, J.M., Fenster, M.J., \& Langford, G. (2004). Attitudes towards physical education: a study of high college students from four countries Austria, Czech Repulic, England and USA. College Student Journal, 32(2), 171-179.

Subramaniam, P.R. \& Silverman, S. (2007). Middle school students' attitudes toward physical education. Teaching and Teacher Education, 23, 602-611. 
Şişko, M., \& Demirhan, G. (2002). The attitudes of male and female students from the primary and secondary schools towards physical education courses. $\mathrm{Ha}$ cettepe University Journal of Education, 23, 205-210.

Tremayne, P. (1995). Children and sport psychology. In T. Morris \& J. Sunders (Eds.), Sport Psychology: Theory, applications and issues. Chichester: Wiley. Pp.. 516-537.

Trudeau, F., \& Shephard, R.J. (2005). Contribution of school programmes to physical activity levels and attitudes in children and adults. Journal of Sports Medicine, 35(2), 98-100.

Yenilmez, K., \& Özabacı, N.Ş. (2003). Yatılı öğretmen okulu öğrencilerinin matematik ile ilgili tutumları ve matematik kaygı düzeyleri arasındaki ilişki üzerine bir araştırma. Pamukkale Üniversitesi Eğitim Fakültesi Dergisi, 14, 132-146.

Yıldıran, İ., Yetim, A., \& Şenel, Ö. (1996). Farklı cinsiyetteki lise öğrencilerinin beden eğitimi dersinden beklentileri. Beden Eğitimi ve Spor Bilimleri Dergisi, 1, 52-57. 